surgery: a randomized controlled trial. J Thorac Cardiovasc Surg. 2011;142: 148-54.

17. Jenkins KJ, Gauvreau K, Newburger JW, Spray TL, Moller JH, Iezzoni LI. Consensus-based method for risk adjustment for surgery for congenital heart disease. J Thorac Cardiovasc Surg. 2002;123:110-8.

18. Björkqvist M, Källman J, Fjaertoft G, Xu S, Venge P, Schollin J. Human neutrophil lipocalin: normal levels and use as a marker for invasive infection in the newborn. Acta Paediatr. 2004;93:534-9.

19. Frässdorf J, De Hert S, Schlack W. Anaesthesia and myocardial ischaemia/reperfusion injury. Br J Anaesth. 2009;103:89-98.

20. Bellomo R, Ronco C, Kellum JA, Mehta RL, Palevsky P, Acute Dialysis Quality Initiative workgroup. Acute renal failure-definition, outcome measures, animal models, fluid therapy and information technology needs: the Second International Consensus Conference of the Acute Dialysis Quality Initiative (ADQI) Group. Crit Care. 2004;8:R204-12.
21. Pedersen KR, Ravn HB, Hjortdal VE, Nørregaard R, Povlsen JV. Neutrophil gelatinase-associated lipocalin (NGAL): validation of commercially available ELISA. Scand J Clin Lab Invest. 2010;70:374-82.

22. Andreasen JB, Johnsen SP, Ravn HB. Junctional ectopic tachycardia after surgery for congenital heart disease in children. Intensive Care Med. 2008;34: 895-902.

23. Kanoria S, Jalan R, Seifalian AM, Williams R, Davidson BR. Protocols and mechanisms for remote ischemic preconditioning: a novel method for reducing ischemia reperfusion injury. Transplantation. 2007;84:445-58.

24. Eichler I, Nilsson M, Rath R, Enander I, Venge P, Koller DY. Human neutrophil lipocalin, a highly specific marker for acute exacerbation in cystic fibrosis. Eur Respir J. 1999;14:1145-9.

25. Eagan TM, Damås JK, Ueland T, Voll-Aanerud M, Mollnes TE, Hardie JA, et al Neutrophil gelatinase-associated lipocalin: a biomarker in COPD. Chest. 2010; 138:888-95.

\title{
Remote ischemic preconditioning for renal protection in children undergoing surgery for complex congenital heart disease: What do we know now and where do we go next?
}

\author{
James S. Tweddell, MD
}

In 1986, Murry, Jennings, and Reimer ${ }^{1}$ found in a canine model that brief periods of occlusion of the circumflex coronary artery preceding a 40-minute period of ischemia followed by reperfusion could reduce the size of the resultant infarct. This phenomenon was termed "preconditioning." Subsequent work found that this protective effect could be elicited by creating brief ischemic episodes in tissue beds remote from the organ to be rendered ischemic. The protective effect of these remote ischemic events could even occur simultaneous to (percondititioning) or after (postconditioning) the ischemic insult. ${ }^{2}$

Remote ischemic preconditioning (RIPC) has been shown in 2 randomized controlled trials to improve cardiac and pulmonary function in children undergoing cardiac surgery. ${ }^{3,4}$ Other investigators have shown that RIPC has

\footnotetext{
From the Department of Cardiothoracic Surgery, Children's Hospital of Wisconsin, Milwaukee, Wis.

Disclosures: The author has nothing to disclose with regard to commercial support. Received for publication Sept 26, 2011; accepted for publication Oct 20, 2011; available ahead of print Nov 21, 2011.

Address for reprints: James S. Tweddell, MD, Department of Cardiothoracic Surgery, Children's Hospital of Wisconsin, 9000 W Wisconsin Ave, MS 715, Milwaukee, WI 53226 (E-mail: tweddell@ @ chw.org).

J Thorac Cardiovasc Surg 2012;143:583-4

$0022-5223 / \$ 36.00$

Copyright (C) 2012 by The American Association for Thoracic Surgery

doi:10.1016/j.jtcvs.2011.10.047
}

a favorable impact on renal function. ${ }^{5}$ RIPC is an attractive and exciting area of study. The technique unmasks an innate ability to ameliorate ischemia-reperfusion (I-R) injury. No drugs are required and the technique of RIPC appears to have little or no potential for morbidity.

In the current study, the group from Aarhus University Hospital, Skejby, Denmark, performed an extremely well-structured randomized double-blind placebocontrolled trial of RIPC to assess the potential for protection of renal function among children undergoing cardiac surgery. ${ }^{6}$ On the basis of their initial hypothesis, they found that RIPC provided no protection of renal function in children operated on for complex congenital heart disease. Despite the ultimate clinical study design, perhaps the optimal technique of RIPC for renal protection in this patient population has not been identified. Do we know enough about the proper timing, duration, type, and quantity of vascular bed to be rendered temporarily ischemic to merit a randomized trial? A subanalysis did identify a benefit among patients greater than 6 months of age, suggesting that there is an age-dependent response to RIPC. Clearly, younger patients are at increased risk of I-R injury and multiorgan dysfunction after operations using cardiopulmonary bypass. Any protective impact of RIPC may have been overwhelmed by increased I-R injury seen in young infants. 
The authors of this study readily acknowledge its shortcomings. They had postulated an ambitious $30 \%$ reduction in incidence of acute renal injury, whereas they observed a more modest reduction of $10 \%$. Using this $10 \%$ difference, they would have needed a much larger $(n=480)$ sample size. What next? Further study might look at organ-specific preconditioning with age-specific "doseresponse curves" among the most susceptible groups. A $10 \%$ reduction in the incidence of acute renal injury could be of clinical benefit, and a multicenter trial might accrue enough patients within a realistic time frame to see whether this reduction in acute renal injury would be realized. Like all well-designed studies, this one by Pedersen and colleagues identifies areas of future study and adds significantly to our understanding of RIPC.

\section{References}

1. Murry CE, Jennings RB, Reimer KA. Preconditioning with ischemia: a delay of lethal cell injury in ischemic myocardium. Circulation. 1986;74:1124-36.

2. Kharbanda RK, Nielsen TT, Redington AN. Translation of remote ischaemic preconditioning into clinical practice. Lancet. 2009;374:1557-65.

3. Cheung MM, Kharbanda RK, Konstantinov IE, Shimizu M, Frndova H, Li J, et al. Randomized controlled trial of the effects of remote ischemic preconditioning on children undergoing cardiac surgery: first clinical application in humans. J Am Coll Cardiol. 2006;47:2277-82.

4. Zhou W, Zeng D, Chen R, Liu J, Yang G, Liu P, et al. Limb ischemic preconditioning reduces heart and lung injury after an open heart operation in infants. Pediatr Cardiol. 2010;31:22-9.

5. Ali ZA, Callaghan CJ, Lim E, Ali AA, Nouraei SA, Akthar AM, et al. Remote ischemic preconditioning reduces myocardial and renal injury after elective abdominal aortic aneurysm repair: a randomized controlled trial. Circulation. 2007; 116(11 Suppl):I98-105.

6. Pedersen K, Ravn H, Povlsen J, Schmidt M, Erlandsen E, Hjortdal V. Failure of remote ischemic preconditioning to reduce the risk of postoperative acute kidney injury in children undergoing operation for complex congenital heart disease: a randomized single-center study. J Thorac Cardiovasc Surg. 2012;143:576-83. 